\title{
A descriptive study of allergen-specific lgE serological tests for canine atopic dermatitis in Thailand
}

\author{
Suttiwee Chermprapai ${ }^{1,2}$ and Naris Thengchaisri ${ }^{1 *}$ (D)
}

\begin{abstract}
Background: This study describes the usefulness of allergen-specific Immunoglobulin E (lgE) serology (ASIS) for identifying allergens in dogs with atopic dermatitis. ASIS tests were conducted in 23 dogs diagnosed with atopic dermatitis for indoor allergens (yeast and mites), outdoor allergens (grass pollen, weed pollen, and tree pollen), and fleas. The relationship among positive ASIS tests were determined using Pearson's correlation coefficient ( $r$ ).

Results: Of the atopic dogs, 26.09\%, 4.35\%, and $47.83 \%$ had positive ASIS tests for only indoor allergens, only outdoor allergens, and both indoor and outdoor allergens, respectively. The prevalence of positive ASIS tests was highest for mites (69.57\%) and did not differ between indoor and outdoor allergens by age, breed, or sex. The prevalence of positive ASIS tests for indoor allergens during the rainy season (84.21\%) was significantly higher than during winter $(25.00 \%, P$-value $=0.030)$. The correlation coefficient of the ASIS results among the outdoor allergens indicated a strong correlation between grass and tree pollen $(r=0.840, P$-value $<0.01)$, grass and weed pollen $(r=0.812, P$-value $<0.01)$, and tree and weed pollen $(r=0.714$, $P$-value $<0.01)$. The correlation coefficient of the ASIS results of $D$. farinae indicated a strong correlation with $A$. siro $(r=0.951, P$-value $<0.01)$ and a moderate correlation with $B$. tropicalis $(r=0.656$, $P$-value $<0.01)$ and T. putrescentie $(r=0.672, P$-value $<0.01)$.
\end{abstract}

Conclusions: ASIS tests are useful in screening for multiple allergens in dogs with atopic dermatitis. Dust mites are an important source of indoor allergens and may be responsible for a higher titer of IgE antibodies against indoor allergens during the rainy season.

Keywords: Allergy, Allergen-specific lgE test, Atopic dermatitis, Dogs, House dust mite

\section{Background}

Canine atopic dermatitis (CAD) is a chronic multifactorial inflammatory and pruritic allergic skin disease with distinctive clinical features [1]. The pathogenesis of CAD has been linked to skin barrier dysfunction, immune responses to indoor and outdoor allergens, and complicated infections [2-4]. Elevation of serum Immunoglobulin E (IgE) is commonly found in CAD and is believed to be one of the main mediators for hypersensitivity reactions [5]. The

\footnotetext{
*Correspondence: ajnaris@yahoo.com

'Department of Companion Animal Clinical Sciences, Faculty of Veterinary Medicine, Kasetsart University, 10900 Bangkok, Thailand

Full list of author information is available at the end of the article
}

recent development of allergen-specific IgE serology (ASIS) have contributed to the rapid identification of common indoor/outdoor allergens among dogs with atopic dermatitis $(\mathrm{AD})$ [6]. The usefulness of ASIS tests in clinical settings compared with intradermal skin tests (IDTs) for specifying the causal allergens remains controversial [7]. IDTs are commonly used in clinical practice, even though the testing may lead to patient discomfort as well as anaphylactic reactions [5]. ASIS tests cause less pain for canine patients without the need to shave the dog's hair and use sedative agents [7]. The application of ASIS tests in atopic dogs provides a good solution for conditioned patients. 
Different types of allergens can be synchronously investigated within the same test [8]. The most common allergens in CAD are house dust mites, storage mites, pollen, molds, and epidermal allergens; the allergens involved can vary by geographic location [8]. Selecting relevant allergens in a patient's local region helps increase the chance of finding significant test results [7]. Research investigating the usefulness of allergen identification in atopic dogs in Thailand is limited and has been performed only by IDT not ASIS [9]. Previous studies reported the influence of breed on atopic dogs and links to possible genetic-related problems [10]. Findings on the influence of age, body size, and sex among these dogs have been inconsistent [11-13]. It is possible that seasonal influence may also affect the results of ASIS tests [11]. Thailand is located in a tropical region, Southeast Asia, and has three seasons: summer, rainy season, and winter; which differs from temperate and subpolar regions that have four seasons: summer, spring, autumn, and winter [14, 15]. Most earlier studies observed that dogs with $\mathrm{AD}$ tend to develop clinically allergic responses in the spring and summer [16-18].

The objective of the present study was to evaluate the usefulness of ASIS tests for identifying specific indoor and outdoor allergens in atopic dogs. The relationship between positive ASIS results among different allergens, as well as the influence of climate conditions, was compared.

\section{Results}

The percentage of atopic dogs with ASIS tests positive for only indoor allergens (yeast and mites), only outdoor allergens (grass pollen, weed pollen, and tree pollen), and both indoor and outdoor allergens was $26.09 \%, 4.35 \%$, and
47.83\%, respectively (Fig. 1). Of the atopic dogs, $21.74 \%$ had negative ASIS test results. The prevalence of ASIS tests positive for specific allergens from highest to lowest was as follows: mites $(69.57 \%)$, weed pollen $(43.48 \%)$, grass pollen $(34.78 \%)$, tree pollen $(30.43 \%)$, yeast $(30.43 \%)$, and fleas $(0.00 \%)$. The prevalence of positive ASIS results for the allergens examined is shown in Table 1. Among indoor allergens, the prevalence of house dust mites $(D$. farinae $=56.52 \%)$ and storage mites $(T$. prutescentie $=56.52 \%$; A. siro $=52.17 \%$; B. tropicalis $=30.43 \%$ ) was found to be highest. Among outdoor allergens, grass pollen was most prevalent (17.39-30.43\%). The prevalence of positive ASIS tests for indoor and outdoor allergens in atopic dogs did not differ according to age, breed, and sex (Table 2). The number and percentage of atopic dogs with a positive or negative ASIS score for the 6 types of allergens are provided in Table 3. These results indicated that mite and yeast were the predominant indoor allergens, respectively. Weed pollen, tree pollen and grass pollen were the most dominant outdoor allergens, respectively. The share of positive ASIS tests among atopic dogs for indoor allergens during the rainy season $(84.21 \%)$ was significantly higher than that found during the winter season $(25.00 \%, P$ value $=0.030$; Table 4 ). The share of positive ASIS tests for outdoor allergens during the rainy season (52.63\%) was comparable to that found during the winter season $(50.00 \%, P$-value $=0.127$; Table 4$)$.

The correlation coefficient of the ASIS results among the outdoor allergens indicated a strong correlation between grass pollen and tree pollen $(\mathrm{r}=0.840, P$-value $<0.01)$, grass pollen and weed pollen $(\mathrm{r}=0.812, P$-value $<0.01)$, and tree pollen and weed pollen $(\mathrm{r}=0.714, P$-value $<0.01$; Table 5$)$. The correlation coefficient of the ASIS results of $D$. farinae

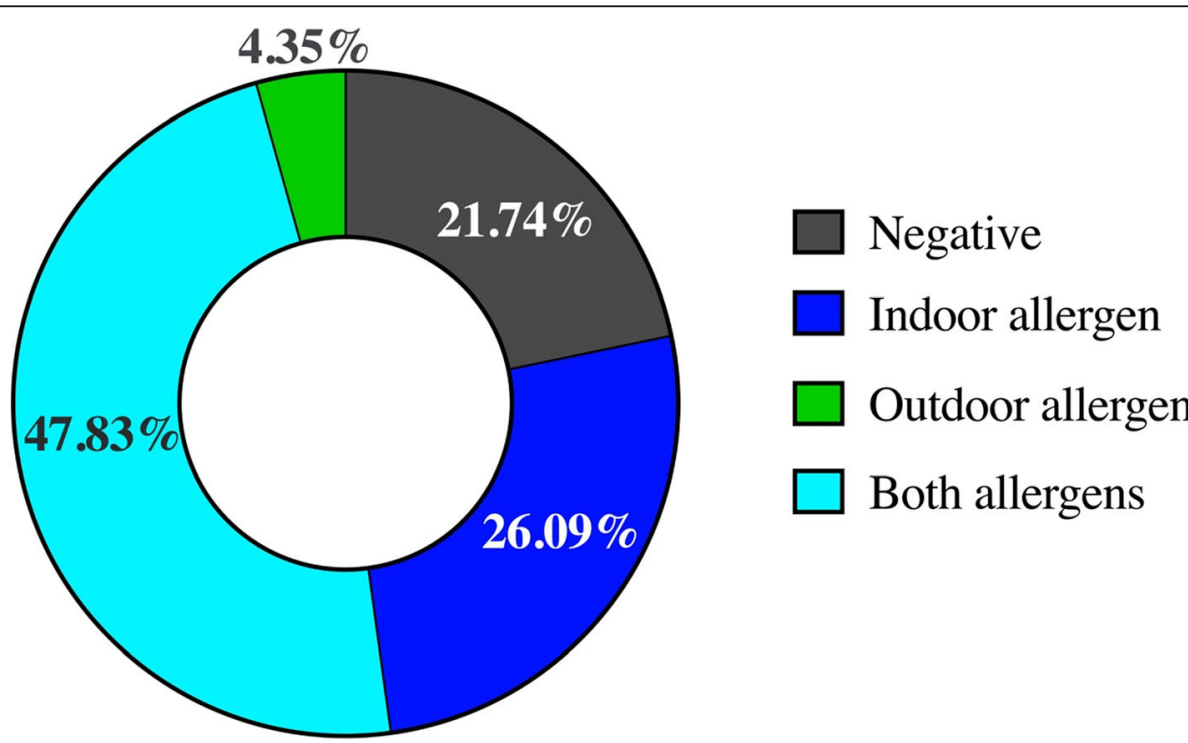

Fig. 1 Summarized results of allergen-specific IgE serological (ASIS) tests in atopic dogs classified by indoor and outdoor allergens 
Table 1 Percentage and number of atopic dogs with positive results to different allergens according to the allergen-specific lgE serological (ASIS) tests

\begin{tabular}{|c|c|c|c|c|}
\hline Number & Name of allergen & Group & Number of positive $\lg E(n=23)$ & Percentage of positive $\lg \mathrm{E}$ \\
\hline 1 & Malassezia pachydermatis & 1 & 7 & 30.43 \\
\hline 2 & Flea saliva & 2 & 0 & 0.00 \\
\hline 3 & Dermatophagoides farinae & 3 & 13 & 56.52 \\
\hline 4 & Blomia tropicalis & 3 & 7 & 30.43 \\
\hline 5 & Tyrophagus putrescentiae & 4 & 13 & 56.52 \\
\hline 6 & Acarus siro & 4 & 12 & 52.17 \\
\hline 7 & Bermuda grass (Cynodon dactylon) & 5 & 5 & 21.74 \\
\hline 8 & Bahia grass (Paspalum notatum) & 5 & 4 & 17.39 \\
\hline 9 & Johnson grass (Sorghum halepense) & 5 & 4 & 17.39 \\
\hline 10 & Meadow fescue (Festuca pratensis) & 5 & 7 & 30.43 \\
\hline 11 & Timothy grass (Phleum pratense) & 5 & 5 & 21.74 \\
\hline 12 & Red/sheep sorrel (Rumex acetosella) & 5 & 6 & 26.09 \\
\hline 13 & Lamb's quarter (Chenopodium album) & 5 & 4 & 17.39 \\
\hline 14 & Russian thistle (Salsola kali) & 6 & 5 & 21.74 \\
\hline 15 & Careless weed (Amaranthus hybridus) & 6 & 5 & 21.74 \\
\hline 16 & Cocklebur (Xanthium strumarium) & 6 & 3 & 13.04 \\
\hline 17 & Marsh elder (Cyclachaena xanthiifolia) & 6 & 3 & 13.04 \\
\hline 18 & $\begin{array}{l}\text { Common and giant ragweed } \\
\text { (Ambrosia artemisiifolia and A. trifida) }\end{array}$ & 6 & 5 & 21.74 \\
\hline 19 & English plantain (Plantago lanceolate) & 6 & 5 & 21.74 \\
\hline 20 & Mugwort (Artemisia vulgaris) & 6 & 2 & 8.70 \\
\hline 21 & Paperbark tree (Maleleuca quinquenervia) & 7 & 2 & 8.70 \\
\hline 22 & White mulberry (Morus alba) & 7 & 4 & 17.39 \\
\hline 23 & $\begin{array}{l}\text { Queen and oil palms } \\
\text { (Arecastrum romanzoffianum and Elaeis guineensis) }\end{array}$ & 7 & 5 & 21.74 \\
\hline 24 & White oak (Quercus alba) & 7 & 3 & 13.04 \\
\hline
\end{tabular}

Group category 1: Yeast, 2: Flea, 3: House dust mite, 4: Storage mite, 5: Grass pollen, 6: Weed pollen, 7: Tree pollen

(Table 5) indicated a strong correlation with $A$. siro $(\mathrm{r}=$ $0.951, P$-value $<0.01)$ and a moderate correlation with $B$. tropicalis $(\mathrm{r}=0.656, P$-value $<0.01)$ and $T$. putrescentie $(\mathrm{r}=$ $0.672, P$-value $<0.01)$.

\section{Discussion}

In the present study, ASIS tests were performed for dogs with atopic dermatitis across 24 allergens. Our findings indicate the important role of indoor allergens over outdoor allergens. House dust mites and storage mites were the predominant allergens among the atopic dogs. We also identified that during the raining season, indoor allergens were the main source of allergens. It should be noted that the positive ASIS results of the outdoor allergens (grass pollen, weed pollen, and tree pollen) were highly correlated. Positive ASIS results for house dust mite allergens were moderately to highly associated with positive ASIS results for storage mites.
Unlike human medicine, for which several atopic dermatitis-related genes have been studied $[19,20]$, only the gene related to IgE production has received attention in veterinary medicine, and a limited correlation has been observed between clinical atopic dermatitis development and IgE levels or other genes [21-24]. The updated practical guidelines to diagnose CAD include ruling out other pruritic skin diseases, interpreting the clinical features as described as Favrot's criteria, and identifying causal allergens either through IDTs or ASIS testing [7]. Although ASIS can have poorer specificity and lower positive predictive value compared with IDTs, ASIS tests provide several advantages over IDTs, such as (1) no patient risk related to sedation or of anaphylactic reactions, (2) convenience (no hair clipping, no restraint), (3) a lower likelihood of influence related to prior or current drug therapy, and (4) shorter duration (easily done in a minute) [25]. Identifying allergens by ASIS testing is favorable when patients have certain 
Table 2 Allergen-specific lgE serological (ASIS) test results in atopic dogs by age, sex, and breed

\begin{tabular}{|c|c|c|c|c|c|}
\hline Category & Subtype & No. positive & No. negative & $\%$ positive & $P$-value \\
\hline \multicolumn{6}{|c|}{ Indoor IgE allergens } \\
\hline \multirow[t]{2}{*}{ Age group } & Young (1-3 years) & 7 & 1 & 87.50 & - \\
\hline & Adult (> 3 years) & 10 & 5 & 67.67 & 0.369 \\
\hline \multirow[t]{3}{*}{ Breed } & Small & 4 & 2 & 67.67 & - \\
\hline & Medium & 8 & 3 & 72.73 & 1.000 \\
\hline & Large & 5 & 1 & 83.33 & 1.000 \\
\hline \multirow[t]{2}{*}{ Sex } & Male & 7 & 4 & 63.64 & - \\
\hline & Female & 10 & 2 & 83.33 & 0.371 \\
\hline \multicolumn{6}{|c|}{ Outdoor IgE allergens } \\
\hline \multirow[t]{2}{*}{ Age group } & Young (1-3 years) & 5 & 3 & 62.50 & - \\
\hline & Adult (> 3 years) & 7 & 8 & 46.67 & 0.667 \\
\hline \multirow[t]{3}{*}{ Breed } & Small & 2 & 4 & 33.33 & - \\
\hline & Medium & 8 & 3 & 72.73 & 0.162 \\
\hline & Large & 2 & 4 & 33.33 & 1.000 \\
\hline \multirow[t]{2}{*}{ Sex } & Male & 4 & 7 & 36.36 & - \\
\hline & Female & 8 & 4 & 66.67 & 0.220 \\
\hline
\end{tabular}

limitations that preclude the use of an IDTs, like most of the patients enrolled in this study. In the current study, there were some dogs with clinical features of $\mathrm{AD}$ but an undetectable IgE response to allergens; this can be explained by the possible confounding problems of recruiting patients with atopic-like dermatitis or by the fact that the ASIS testing cannot detect the presence of cutaneous mast cells with reaginic antibodies present on the mast cells $[25,26]$.

It has been described previously that ASIS tests measured by enzyme-linked immunosorbent assay (ELISA) can be analyzed by using mono- or polyclonal antibodies or the high-affinity Fc epsilon receptor alpha chain protein (FceRI $\alpha$ ), and positive results have varied among these assays [27, 28]. Although the chance of crossreactivity between IgE and IgG has been discussed [29], the serum samples of this study were analyzed by the patented Fc- $\varepsilon$ receptor testing method (Allercept), which can provide a low chance of cross-reactivity of positive results [30]. However, the cross-reactivity in the same group of allergens, such as house dust and storage mites, remains and cannot be ruled out [31]. Another study demonstrated that the prevalence of positive ASIS results using the high-affinity FceRI $\alpha$ was similar or even better than the results of IDTs [32]. It is noteworthy that the correlation between the results of ASIS tests and IDTs possibly ranged from weak to strong depending on numerous factors, including standardization of allergens, testing technique and laboratory conditions, or individual factors [33-35]. Positive results of IDTs and ASIS tests should be compared with caution. The proper selection of diagnostic tools helps improve the sensitivity and the specificity of the test and thus the ability to reliably identify patients' clinically relevant allergens.

Table 3 Percentage and number of atopic dogs according to allergen specific lgE serological (ASIS) scores among different groups of allergens (yeast, mites, grass pollen, weed pollen, and tree pollen)

\begin{tabular}{|c|c|c|c|c|}
\hline Allergy group & $\begin{array}{l}\text { No. of dogs with } \\
\text { lgE score of } 2-4\end{array}$ & $\begin{array}{l}\text { No. of dogs with } \\
\text { lgE score of } 0-1\end{array}$ & $\%$ positive & $P$-value \\
\hline Yeast & 7 & 16 & 30.43 & - \\
\hline Flea & 0 & 23 & 0.00 & 0.004 \\
\hline Mite & 16 & 7 & 69.57 & 0.008 \\
\hline Grass pollen & 8 & 15 & 34.78 & 0.753 \\
\hline Weed pollen & 10 & 13 & 43.48 & 0.360 \\
\hline Tree pollen & 7 & 16 & 30.43 & 1.000 \\
\hline Overall & 18 & 5 & 78.26 & 0.003 \\
\hline
\end{tabular}


Table 4 Seasonal effects on the results of allergen-specific lgE serological (ASIS) tests in atopic dogs

\begin{tabular}{llcccc}
\hline Category & Season & No. positive & No. negative & \% positive & $P$-value \\
\hline Indoor allergens & Rainy & 16 & 3 & 84.21 & - \\
& Winter & 1 & 3 & 25.00 & 5.030 \\
Outdoor allergens & Rainy & 10 & 9 & 5.63 & - \\
& Winter & 2 & 2 & 80.00 & 0.127 \\
Both indoor and outdoor allergens & Rainy & 16 & 3 & 50.00 & - \\
& Winter & 2 & 2 & 0.064 \\
\hline
\end{tabular}

Performing both an IDTs and ASIS testing can provide better outcomes with which to interpret an allergic response to tested allergens [36].

The clinical signs of CAD vary depending on several factors, including age of onset, breed, sex, anatomical site, type of skin lesion, and seasonality [11]. Seasonality varies with respect to geographic location and relates to environmental allergens [11]. Spring and summer have been most commonly described as related to the development and progression of allergic responses [16, 17]. Thailand is located in Southeast Asia and has three seasons: summer, the rainy season, and winter [15]. In our study, most of the patients' serum samples were taken in the rainy and winter seasons with regard to the clinical presentation. It was found that during the rainy season, indoor allergens were the main source of the allergens compared with the outdoor allergens. House dust mites, the major indoor allergen related to atopic dermatitis, prefer tropical and subtropical climates with relatively high humidity $[37,38]$. When rainfall is heavy during the rainy season in Thailand, owners likely keep their animals indoors more often, which may lead to increased exposure to house dust

Table 5 Pearson's correlation coefficient ( $r$ ) among groups of indoor allergen (A. siro, B. tropicalis, D. farinae, T. putrescentie) or outdoor allergens (yeast, mites, grass pollen, weed pollen, and tree pollen) in atopic dogs based on allergen-specific lgE serological (ASIS) tests

\begin{tabular}{|c|c|c|c|c|}
\hline \multicolumn{5}{|c|}{ Indoor IgE allergens } \\
\hline Mite allergen & Acarus siro & $\begin{array}{l}\text { Blomia } \\
\text { tropicalis }\end{array}$ & D. farinae & \\
\hline $\begin{array}{l}\text { Tyrophagus } \\
\text { putrescentie }\end{array}$ & $0.789^{* *}$ & $0.616^{* *}$ & $0.672^{* *}$ & \\
\hline Acarus siro & - & $0.716^{* *}$ & $0.951^{* *}$ & \\
\hline Blomia tropicalis & - & - & $0.656^{* *}$ & \\
\hline \multicolumn{5}{|c|}{ Outdoor lgE allergens } \\
\hline Allergen group & $\begin{array}{l}\text { Grass } \\
\text { pollen }\end{array}$ & Weed pollen & $\begin{array}{l}\text { Tree } \\
\text { pollen }\end{array}$ & Yeast \\
\hline Mite & 0.288 & 0.305 & 0.288 & 0.308 \\
\hline Grass pollen & - & $0.812^{* *}$ & $0.840^{* *}$ & 0.205 \\
\hline Weed pollen & - & - & $0.714^{* *}$ & 0.346 \\
\hline Tree pollen & - & - & - & 0.140 \\
\hline
\end{tabular}

** Indicates a $P$-value of $<0.01$ mites. The effect of seasonality on CAD development should be further studied and include all the seasons involved in the studied region.

The limitations of the present study include the crossreactivity, the seasonality effects, and the downsides of ASIS testing mentioned earlier, as well as the sample size. No significant differences in positive ASIS results were observed for indoor and outdoor allergens based on age, breed, or sex. Given the retrospective nature of the present study, we did not have cases with flare-up symptoms in summer during the period of the current study for ASIS testing. More studies can be performed to identify the possible risks associated with the raining season resulting in the flare-up symptoms of the atopic dogs. It is possible that the sample size used in the present study may be limited for identifying difference in positive ASIS based on age, breed, or sex. Although none of the atopic dogs enrolled in this study had positive ASIS results for flea antigens, this finding is fairly in agreement with earlier studies that found only a low prevalence of positive results for flea antigens [12, 39]. Improved population sampling and/or increased sample size of the study may have provided a more rigid conclusion about serology testing for dermatitis related to flea allergies as well as multivariate analysis of the factors associated with CAD.

\section{Conclusions}

Multiallergen screening using ASIS tests revealed that house dust mites and weed pollen are the most important sources of allergens in Thailand. The present findings indicated that during the rainy season, atopic dogs may experience a higher titer of IgE antibodies against indoor allergens. Cross-reactivities from ASIS tests likely occurred among dust mite allergens as well as different types of pollen. ASIS testing serves the purpose of identifying allergens that may be included in the treatment. The application of ASIS tests in atopic dogs provides a good solution for conditioned patients.

\section{Methods}

Animals

This study was approved by the Kasetsart University Institutional Animal Care and Use Committee (ACKU63- 
VET-044) and by the Ethical Review Board of the Office of National Research Council of Thailand (NRCT license No. U1-08491-2562). Twenty-three client-owned dogs with atopic dermatitis (12 females and 11 males, median age of $4.3 \pm 4.0$ years) of different breeds that visited the Dermatology Unit at Kasetsart University Veterinary Teaching Hospital from 2017 to 2019 were included. The dog owners were informed and educated about the practical approach of pruritic problem. The dogs met Favrot's diagnostic criteria for atopic dermatitis, and other pruritic skin diseases were ruled out by direct examination of the ectoparasites, coat brushing, skin scrapings, and regular use of antiparasitic control [7]. Infection and inflammation caused by bacteria, fungi, and/ or yeast were ruled out by skin cytology. Adverse food reaction was ruled out by an elimination diet trial of 812 weeks. No concurrent anti-inflammatory, antihistamine or antibacterial/antifungal treatments were allowed during the elimination diet trial or 4 weeks prior to serum collection for ASIS.

\section{Allergen-specific IgE serology (ASIS)}

At least $5 \mathrm{~mL}$ of serum sample was collected from each dog by cephalic venipuncture and dogs were returned to the owner after blood collections. All serum samples were submitted to Animal Allergy Lab, Heska's International Lab Partners in Singapore, for measurement of allergenspecific IgE (Allercept ${ }^{\circ}$ allergen specific IgE test, Heska Corp., Singapore). The Asian panel was categorized into 7 groups, including indoor and outdoor allergens and fleas (Table 1). The indoor allergens included were house dust mites (Dermatophagoides farinae and Blomia tropicalis), storage mites (Tyrophagus putrescentiae), and flour mites (Acarus siro). The outdoor allergens included were Bermuda grass (Cynodon dactylon), Bahia grass (Paspalum notatum), Johnson grass (Sorghum halepense), meadow fescue (Festuca pratensis), Timothy grass (Phleum pratense), red/sheep sorrel (Rumex acetosella), lamb's quarter (Chenopodium album), Russian thistle (Salsola kali), careless weed (Amaranthus hybridus), cocklebur (Xanthium strumarium), marsh elder (Cyclachaena xanthiifolia), common and giant ragweed (Ambrosia artemisiifolia and $A$. trifida), English plantain (Plantago lanceolata), mugwort (Artemisia vulgaris), paperbark tree (Maleleuca quinquenervia), white mulberry (Morus alba), queen and oil palms (Arecastrum romanzoffianum and Elaeis guineensis), and white oak (Quercus alba). Yeast (Malassezia pachydermatis) and fleas (flea saliva), commonly related to CAD, were also included in the analysis. For further information regarding the identification of plant materials as well as the acquisition of allergens, please visit the company website (www.heska. com). Based on the concentrations of IgE measured, results were stratified into one of four classes: $0=$ no reaction, $1=$ a light nonspecific reaction, $2=$ a weak positive reaction, $3=$ a moderate positive reaction, and $4=\mathrm{a}$ strong positive reaction. Reactions of greater than or equal to 2 were considered positive ASIS test results.

\section{Statistical analysis}

The sample size was calculated using freely downloadable software G*Power3.1 (Faul, Erdfelder, Lang and Buchner, 2007) to detect a difference using an exact test with alpha $=0.05$ (two-tailed test), beta $=0.9$, and an effect size of 0.25 . The data were analyzed using STATA12 (StataCorp, College Station, Texas, USA) and GraphPad Prism Version 6 (GraphPad Software, San Diego, California, USA). The prevalence of ASIS results for different allergens, as well as the prevalence of ASIS results acquired during the rainy season and winter, was compared using Fisher's exact test. The relationship among ASIS results for different allergens was determined using Pearson's correlation coefficient (r). A $P$-value $<0.05$ was considered statistically significant.

\section{Abbreviations \\ AD: Atopic dermatitis; ASIS: Allergen-specific IgE serology; CAD: Canine atopic dermatitis; IDT: Intradermal skin tests; IgE: Immunoglobulin E \\ Acknowledgements \\ The authors would like to thank all staff at the Dermatology unit, Kasetsart University Veterinary Teaching Hospital, Bangkok, and the owners of the dogs that participated in this study. Vet Diags Co., Ltd, the distributor in Thailand, helped submit serum samples to Animal Allergy Lab, Heska's International Lab Partners in Singapore.}

\section{Authors' contributions}

SC developed the concept, designed the study, performed the experiment, performed statistical analysis, and wrote the manuscript. NT designed the study, performed statistical analysis, and revised the manuscript. All authors contributed to the drafting and revision of the manuscript. All authors read and approved the final manuscript.

\section{Funding}

The present study was financially supported by the Faculty of Veterinary Medicine (start-up research fund to SC), Kasetsart University.

\section{Availability of data and materials}

The data used and/or analyzed in the present study are available from the corresponding author on reasonable request.

\section{Ethics approval and consent to participate}

The protocol was approved by the Kasetsart University Institutional Animal Care and Use Committee and by the Ethical Review Board of the Office of National Research Council of Thailand (NRCT license U1-08491-2562). Informed written consent was obtained from all dog owners and the experiment complied with the Kasetsart University Institutional Animal Care and Use Standards.

\section{Consent for publication}

Not applicable.

\section{Competing interests}

The authors declare that they have no competing interests.

\section{Author details}

${ }^{1}$ Department of Companion Animal Clinical Sciences, Faculty of Veterinary Medicine, Kasetsart University, 10900 Bangkok, Thailand. Dermatology Unit, Kasetsart University Veterinary Teaching Hospital, 10900 Bangkok, Thailand. 
Received: 2 October 2020 Accepted: 19 November 2020

Published online: 07 December 2020

\section{References}

1. Halliwell R. Revised nomenclature for veterinary allergy. Vet Immunol Immunopathol. 2006;114:207-8

2. Chermprapai S, Broere F, Gooris G, Schlotter YM, Rutten VPMG, Bouwstra JA Altered lipid properties of the stratum corneum in Canine Atopic Dermatitis. Biochim Biophys Acta - Biomembr. 2018;1860:526-33.

3. Pucheu-Haston CM, Bizikova P, Marsella R, Santoro D, Nuttall T, Eisenschenk MN. Review: Lymphocytes, cytokines, chemokines and the T-helper 1-Thelper 2 balance in canine atopic dermatitis. Vet Dermatol. 2015;26:124-e32.

4. Chermprapai S, Ederveen THA, Broere $F$, et al. The bacterial and fungal microbiome of the skin of healthy dogs and dogs with atopic dermatitis and the impact of topical antimicrobial therapy, an exploratory study. Vet Microbiol. 2019;229:90-9.

5. Hillier A, DeBoer DJ. The ACVD task force on canine atopic dermatitis (XVII): intradermal testing. Vet Immunol Immunopathol. 2001;81:289-304.

6. Plant JD, Neradelik MB, Polissar NL, Fadok VA, Scott BA. Agreement between allergen-specific lgE assays and ensuing immunotherapy recommendations from four commercial laboratories in the USA. Vet Dermatol. 2014;25:15-e6.

7. Hensel P, Santoro D, Favrot C, Hill P, Griffin C. Canine atopic dermatitis: detailed guidelines for diagnosis and allergen identification. BMC Vet Res. 2015:11:195-6.

8. Neuber A, Nuttall T. Allergy testing. In: Neuber A, Nuttall T, editors Diagnostic Techniques in Veterinary Dermatology. Hoboken: Wiley; 2017. p. 125-58.

9. Chanthick C, Anaman S, Buathet K. The prevalence of positive intradermal allergy tests in 114 dogs with atopic dermatitis in the Bangkok metropolis, Thailand. Vet Immunol Immunopathol. 2008;126:256-62

10. Bizikova P, Pucheu-Haston CM, Eisenschenk MN, Marsella R, Nuttall T, Santoro D. Review. Role of genetics and the environment in the pathogenesis of canine atopic dermatitis. Vet Dermatol. 2015;26:95-e26.

11. Bizikova P, Santoro D, Marsella R, Nuttall T, Eisenschenk MNC, PucheuHaston CM. Review: Clinical and histological manifestations of canine atopic dermatitis. Vet Dermatol. 2015:26:79-e24.

12. Bjelland AA, Dolva FL, Nødtvedt A, Sævik BK. Prevalence of and risk factors for increased serum levels of allergen-specific lgE in a population of Norwegian dogs. Acta Vet Scand. 2014;56:81.

13. Jang H-M, Yeo G-S, Kim J-H, et al. Prevalence of serum allergen-specific immunoglobulin E for canine atopic dermatitis in Korea. J Biomed Res. 2014;15:162-9.

14. Caraballo L, Zakzuk J, Lee BW, et al. Particularities of allergy in the Tropics. World Allergy Organ J. 2016;9:20.

15. Loo YY, Billa L, Singh A. Effect of climate change on seasonal monsoon in Asia and its impact on the variability of monsoon rainfall in Southeast Asia. Geosci Front. 2015;6:817-23.

16. Tarpataki N, Papa K, Reiczigel J, Vajdovich P, Vorosi K. Prevalence and features of canine atopic dermatitis in Hungary. Acta Vet Hung. 2006;54: 353-66

17. Zur G, lhrke PJ, White SD, Kass PH. Canine atopic dermatitis: a retrospective study of 266 cases examined at the University of California, Davis, 19921998. Part I. Clinical features and allergy testing results. Vet Dermatol. 2002; 13:89-102.

18. Favrot C, Steffan J, Seewald W, Picco F. A prospective study on the clinical features of chronic canine atopic dermatitis and its diagnosis. Vet Dermatol. 2010;21:23-31

19. Barker JNWN, Palmer CNA, Zhao Y, et al. Null Mutations in the Filaggrin Gene (FLG) Determine Major Susceptibility to Early-Onset Atopic Dermatitis that Persists into Adulthood. J Invest Dermatol. 2007;127:564-7.

20. Sugiura $H$, Ebise $H$, Tazawa $T$, et al. Large-scale DNA microarray analysis of atopic skin lesions shows overexpression of an epidermal differentiation gene cluster in the alternative pathway and lack of protective gene expression in the cornified envelope. Br J Dermatol. 2005;152:146-9.

21. Sousa CA, Marsella R. The ACVD task force on canine atopic dermatitis (II): genetic factors. Vet Immunol Immunopathol. 2001;81:153-7.

22. Egli KS, Schiessl B, Roosje PJ, et al. Evaluation of the usefulness of sensitization to aeroallergens as a model for canine atopic dermatitis in genetically predisposed Beagles. Am J Vet Res. 2002;63:1329-36.
23. Salzmann CA, Olivry TJM, Nielsen DM, Paps JS, Harris TL, Olby NJ. Genomewide linkage study of atopic dermatitis in West Highland White Terriers. BMC Genet. 2011;12:37.

24. Wood SH, Ollier WE, Nuttall T, McEwan NA, Carter SD. Despite identifying some shared gene associations with human atopic dermatitis the use of multiple dog breeds from various locations limits detection of gene associations in canine atopic dermatitis. Vet Immunol Immunopathol. 2010; 138:193-7.

25. Marsella R. Hypersensitivity disorders. In: Miller WH, Griffin CE, Campbell KL, Muller GH, editors. Muller and Kirk's Small Animal Dermatology7: Muller and Kirk's Small Animal Dermatology. St. Louis: Elsevier/Mosby; 2013. pp. 363-431.

26. Olivry T, DeBoer DJ, Favrot $C$, et al. Treatment of canine atopic dermatitis: 2010 clinical practice guidelines from the International Task Force on Canine Atopic Dermatitis. Vet Dermatol. 2010;21:233-48.

27. Stedman K, Lee K, Hunter S, Rivoire B, McCall C, Wassom D. Measurement of canine IgE using the alpha chain of the human high affinity IgE receptor. Vet Immunol Immunopathol. 2001;78:349-55.

28. Lee KW, Blankenship KD, McCurry ZM, Esch RE, DeBoer DJ, Marsella R. Performance characteristics of a monoclonal antibody cocktail-based ELISA for detection of allergen-specific lgE in dogs and comparison with a high affinity IgE receptor-based ELISA. Vet Dermatol. 2009;20:157-64.

29. DeBoer DJ, Hillier A. The ACVD task force on canine atopic dermatitis (XVI): laboratory evaluation of dogs with atopic dermatitis with serum-based "allergy" tests. Vet Immunol Immunopathol. 2001:81:277-87.

30. Thom N, Favrot C, Failing K, Mueller RS, Neiger R, Linek M. Intra- and interlaboratory variability of allergen-specific lgE levels in atopic dogs in three different laboratories using the Fc- e receptor testing. Vet Immunol Immunopathol. 2010;133:183-9.

31. Saridomichelakis MN, Marsella R, Lee KW, Esch RE, Farmaki R, Koutinas AF. Assessment of cross-reactivity among five species of house dust and storage mites. Vet Dermatol. 2008;19:67-76.

32. Foster AP, Littlewood JD, Webb P, Wood JLN, Rogers K, Shaw SE. Comparison of intradermal and serum testing for allergen-specific lgE using a FceRla-based assay in atopic dogs in the UK. Vet Immunol Immunopathol. 2003;93:51-60.

33. Ginel PJ, Riaño C, Lucena R. Evaluation of a commercial ELISA test for the detection of allergen-specific lgE antibodies in atopic dogs. Zentralb| Veterinarmed B. 1998;45:421-5

34. Codner EC, Lessard P. Comparison of intradermal allergy test and enzymelinked immunosorbent assay in dogs with allergic skin disease. J Am Vet Med Assoc. 1993;202:739-43.

35. Olivry T, Jackson HA, Murphy KM, Tater KC, Roberts M. Evaluation of a pointof-care immunodot assay for predicting results of allergen-specific intradermal and immunoglobulin E serological tests. Vet Dermatol. 2005;16: $117-20$

36. Olivry T, Saridomichelakis M, (ICADA) IC on AD of A. Evidence-based guidelines for anti-allergic drug withdrawal times before allergen-specific intradermal and lgE serological tests in dogs. Vet Dermatol 2013;24:225-e49.

37. Randall A, Hillier A, Cole LK, Kwochka KW, Needham G, Wassom DL. Quantitation of house dust mites and house dust mite allergens in the microenvironment of dogs. Am J Vet Res. 2003;64:1301-9.

38. Nuttall TJ, Hill PB, Bensignor E, Willemse T. House dust and forage mite allergens and their role in human and canine atopic dermatitis. Vet Dermatol. 2006;17:223-35.

39. Sævik BK, Ulstein TL, Larsen HJS. Evaluation of a commercially available enzyme-linked immunosorbent assay for the detection of allergen-specific lgE antibodies in dogs. Res Vet Sci. 2003:74:37-45.

\section{Publisher's Note}

Springer Nature remains neutral with regard to jurisdictional claims in published maps and institutional affiliations. 